$\stackrel{\circ}{\text { II }}$

\title{
DOMNIEMANE I RZECZYWISTE PRZYCZYNY CHIŃSKIEGO CUDU GOSPODARCZEGO. POLEMIKA Z KAZIMIERZEM POZNAŃSKIM
}

ABSTRACT. Domniemane i rzeczywiste przyczyny chińskiego cudu gospodarczego. Polemika $z$ Kazimierzem Poznańskim [Alleged and real reasons for the Chinese economy miracle. A polemic with Kazimierz Poznański] edited by W. Banach, M.A. Michalski, J. Sójka ", Człowiek i Społeczeństwo" vol. XLVI: Między Chinami a Zachodem. Pytanie o źródła chińskiego sukcesu gospodarczego [Between China and the West. An inquiry into the sources of the Chinese economic miracle], Poznań 2018, pp. 67-84, Adam Mickiewicz University. Faculty of Social Sciences Press. ISSN 0239-3271.

China has come a long way in the last hundred years. It is so long that it's easy to forget about the problems that the Chinese had to face earlier. They struggled with patterns of long duration making it difficult for them to break out of the centuries-old stagnation. The Chinese were looking for new patterns of political culture. However, not only those patterns required a correction. If Fukuyama is right, the rules of caring for one's family at the expense of social obligations have turned out to be no less troublesome. The Chinese way to prosperity led then not only through the public sphere, but also through the hearts and minds of the Chinese. They had to cut themselves off from the past. Meanwhile, in the time of economic prosperity, the longing for the past returns. The place of doctrines borrowed from the Western world replaces nostalgia. Deng Xiaoping's political references to the teachings of Confucius are - in the blink of an eye - becoming the basic message. It is not surprising that the Chinese people want to forget about the embarrassing moments of their own history. These trends, however, should not affect external observers of economic life in China. One of such observers is Kazimierz Poznański. He believes that the cause of the Chinese economic miracle is the Confucian ethics (despite the historical changes shaping the Chinese mentality). The aim of the article is to verify this hypothesis.

Przemysław Rotengruber, Uniwersytet im. Adama Mickiewicza w Poznaniu, Wydział Nauk Społecznych, Instytut Kulturoznawstwa, Zakład Etyki Gospodarczej, ul. Szamarzewskiego 89a, 60-568 Poznań, e-mail: proten@amu.edu.pl 


\section{Wprowadzenie}

Spektakularny rozwój gospodarki chińskiej skłania do zadumy. W przeciągu zaledwie czterech dekad Chińska Republika Ludowa pokonała drogę prowadzącą od zapaści, symbolem której była (zakończona w 1976 r.) rewolucja kulturalna Mao Zedonga, do globalnej ekspansji gospodarczej. Jeśli skonfrontować to $\mathrm{z}$ - utrwaloną w świadomości zbiorowej - tezą Maxa Webera o dysfunkcjonalnych wzorach azjatyckiej kultury religijnej ${ }^{1}$, nietrudno wyobrazić sobie, jak wielkim zaskoczeniem dla społeczeństw zachodnich był sukces Państwa Środka. Przekonane o trwałości granic oddzielających - zamieszkiwane przez nie - centra od biznesowych peryferii zrozumiały nagle, że tak wcale być nie musi². Nie było to wprawdzie pierwsze ostrzeżenie. Państwa azjatyckie, począwszy od Japonii wdrażającej reformy od połowy XIX w., wielokrotnie zaskakiwały dynamiką rozwoju oraz polityczną nieprzewidywalnością. Jednak dopiero Chiny zachwiały posadami świata. To potężne państwo dowiodło ponad wszelką wątpliwość, że przyszły podział bogactwa będzie przebiegał według kryteriów innych niż te obowiązujące do niedawna.

Z poczynionych uwag wynika, że reformy gospodarcze w Chinach przestały być sprawą mieszkańców tego kraju. Informacje o ich przebiegu znajdują dziś zastosowanie w prognozowaniu zmian zachodzących w gospodarce światowej. Zasadnicze znaczenie w tym postępowaniu mają ustalenia dotyczące czynników decydujących o powodzeniu chińskiego eksperymentu. Dopiero wiedza o determinantach rozwojowych pozwala bowiem na to, by snuć rozważania na temat praktycznych skutków ich oddziaływania. Tym samym akcent przeniesiony zostaje z danych szczegółowych na sposób ich organizacji. Oczywiście, jedno i drugie jest ważne. Niestety, nie zawsze badacz pamięta o konieczności uwzględnienia (poznawczo ukrytych) uwarunkowań analizowanego procesu bądź zjawiska. Stąd postulat płynnego przechodzenia od czynności sprawozdawczych do systematyzacji wiedzy o tym, co wydarzyło się w określonym miejscu i czasie.

${ }^{1}$ R. Bendix, Max Weber. Portret uczonego, tłum. K. Jakubowicz, Państwowe Wydawnictwo Naukowe, Warszawa 1975, ss. 90, 135-141, 199; por. S. Kozyr-Kowalski, Gesellschaft ohne Wirtschaft: formy recepcji Maxa Webera w socjologii amerykańskiej, w: R. Bendix, op. cit., ss. 458-460.

2 I. Wallerstein, The Modern World-System. The Second Era of Great Expansion of the Capitalist World-Economy, 1730-1840's, New York 1974. 
Wychodząc naprzeciw wyrażonemu oczekiwaniu, Kazimierz Poznański skupia się na wzorach kultury odnoszących się do umiejętności gospodarczej samoorganizacji Chińczyków. Zdaniem ekonomisty ukrytym zasobem tego społeczeństwa jest etyka konfucjańska ${ }^{3}$. Jako synonim ładu spontanicznego reprodukowanego przez nie od czasów niepamiętnych, zapewnia mu przewagę nad jego politycznym otoczeniem. Poznański głosi, że właśnie dzięki obyczajom wyszydzanym w okresie rządów Mao Zedonga (1949-1976) Chińczycy tak łatwo i chętnie zaakceptowali reformy wdrażane od 1978 r. przez Deng Xiaopinga ${ }^{4}$. Ujmując rzecz metaforycznie, powrócili oni do tego, co znali oraz z czym (mimowolnie) się identyfikowali. Powrót do tradycji sprawił z kolei to, że stali się zdolni do stawiania czoła nowym wyzwaniom społecznym i gospodarczym.

Poznański realizuje swój zamysł, wydobywając z nauk Konfucjusza (551-479 p.n.e.) osiem myśli przewodnich określających właściwy stosunek człowieka do siebie, natury oraz społecznego otoczenia. Należy dopowiedzieć, że kluczem do nauk chińskiego mędrca są dla Poznańskiego pisma Mencjusza (ok. 372-289 p.n.e.). Poznański wymienia następujące zasady etyki konfucjańskiej: (1) zachowanie ciągłości rodzaju ludzkiego; (2) działanie w perspektywie obfitości zasobów; (3) uczciwa praca jako sposób ich pozyskiwania; (4) zobowiązania społeczne przed intencją bogacenia się; (5) bezwzględna ochrona rodziny; (6) przeciwdziałanie ubóstwu poprzez ograniczenie nierówności; (7) spolegliwość wobec państwa jako strażnika wartości rodzinnych; a wreszcie (8) przewaga praktyki reprezentowanej przez zdrowy rozsądek nad teorią społeczną i ekonomiczną 5 .

Zestaw wymienionych wzorów kultury odgrywa decydującą rolę w badaniach Poznańskiego nad genezą chińskiego sukcesu gospodarczego. Wzory te, przekonuje autor, zasadnie aspirują do miana warunków wystarczających powodzenia chińskich reform. Tymczasem wyjaśnienie to budzi wątpliwości. Odnoszą się one do dwóch kwestii. Pierwsza z nich dotyczy, powielanych przez chińską wspólnotę kulturową, wzorów długiego trwania ${ }^{6}$

${ }^{3}$ K. Poznański, Ekonomia jako etyka. Podejście konfucjańskie, w: E. Mączyńska, J. Sójka (red.), W stronę nowego paradygmatu, PTE, Warszawa 2017, ss. 82-117.

${ }^{4}$ Za właściwy początek procesu reformowania gospodarki chińskiej uważa się wystąpienie Deng Xiaopinga na III Plenum Komitetu Centralnego Komunistycznej Partii Chin w dniu 13 grudnia 1978 r. Por. D.S.G. Goodman, Deng Xiaoping and the Chinese Revolution: A Political Biography, Routledge, London 1994, s. 126; J. Polit, Chiny, Wyd. Trio, Warszawa 2004, ss. 263-320.

${ }^{5}$ K. Poznański, op. cit.

${ }^{6}$ F. Braudel, Gramatyka cywilizacji, Oficyna Naukowa, Warszawa 2006, s. 55. 
potraktowanych przez Poznańskiego jako panaceum na jej współczesne bolączki. Przekonania o bezwzględnej ważności zobowiązań rodzinnych, bogactwie natury czy metafizycznym (względnie metafizyczno-religijnym) statusie norm społecznych równie dobrze mogą być uznane za czynnik integrujący uczestników życia gospodarczego co zwracający ich przeciwko sobie. To prawda, że prawidłowo funkcjonująca rodzina kształtuje prospołeczne postawy jej członków. Wraz z tym jednak dostarcza im powodów, by rywalizować z otoczeniem - zwłaszcza wtedy, gdy muszą się oni zmierzyć z problemem niedoborów (np. żywności), gdy na próbę zostaje wystawiona ich wiara w nieograniczoność zasobów ekonomicznych (oferowanych przez naturę). Rywalizacja staje się wówczas jedynym sposobem ochrony wartości podstawowej, jaką jest rodzina.

Druga wątpliwość wykracza poza propozycję Poznańskiego. Bez względu na to, do jakich rozstrzygnięć szczegółowych prowadzą badania prowadzone z perspektywy ex post facto, musi towarzyszyć im obawa związana z właściwym doborem klucza interpretacyjnego. Intuicyjny tryb, w jakim się to odbywa, uzasadnia pytanie o prawomocność dokonanego wyboru. Posługując się podręcznikowym przykładem, po II wojnie światowej badacze społeczni prześcigali się w ustaleniach dotyczących powodów, dla których Niemcy padły ofiarą nazistowskiej indoktrynacji. Niestety, na niewiele to się zdało. Zgromadzona wiedza okazała się nieprzydatna w prognozowaniu przyszłych zagrożeń. Co rusz zaskakują nas rodzące się (lub odradzające) nacjonalizmy. W przypadku reformujących się Chin dochodzi do tego inna trudność. Poza obawami związanymi z adekwatnością opisu osobnego uwzględnienia wymagają preferencje badawcze interpretatora. Jakże łatwo czynniki domniemane mogą przesłaniać mu rzeczywiste przyczyny określonego zjawiska bądź procesu. Dlatego tak ważne jest, by badacz skłaniający się ku hipotezie objaśniającej przebieg wydarzeń przeszłych nie tracił z pola widzenia wyjaśnień alternatywnych.

Zgodnie z postulatem sformułowanym powyżej celem artykułu jest poddanie ocenie propozycji Poznańskiego. Dokonana przez niego rekonstrukcja etyki konfucjańskiej skonfrontowana zostanie ze stanowiskiem innych autorów dotyczącym odnoszącym się do konsekwencji posługiwania się przez Chińczyków normami poprawnościowymi składającymi się na wzmiankowany przekaz. Następnie płynące z tego wnioski uzupełnione zostaną pobieżną analizą procesu reformowania gospodarki chińskiej. Kluczowe znaczenie w tym postępowaniu ma porównanie (mierzalnych) oddziaływań polityczno-prawnych z opisem tego, co zaszło, dokonanym za pomocą (słabo mierzalnych) czynników kulturowych. Doprecyzowując myśl, tam, gdzie zmianę tłumaczy interes, rozważania dotyczące cnót aktorów nastawionych 
na jej osiąganie prowadzić trzeba z najdalej idącą ostrożnością. W przeciwnym razie badania kulturowe, zamiast uzupełniać wiedzę o faktach, będą się zwracały przeciwko niej. Rozpoznanie to nie koliduje z wcześniejszym twierdzeniem o konieczności prowadzenia owych badań. Stanowi raczej jego uzupełnienie. Diagnoza kulturowa powinna tyleż objaśniać stan faktyczny, co respektować składające się nań ustalenia. Czy zatem stanowi? To pytanie wytycza kierunek poszukiwań inspirowanych dokonaniami Poznańskiego.

\section{Konfucjanizm jako podstawa nowej ekonomii}

Zdrowy rozsądek podpowiada, że o powodzeniu reform - politycznych lub gospodarczych - decyduje prawidłowe rozpoznanie dysfunkcji, z którymi zmaga się państwo-reformator, oraz wybór środków zaradczych, którymi zamierza się ono posłużyć. To jednak nie wszystko. Przykład reform włoskich, podany przez Roberta Putnama, świadczy o tym, że najstaranniej przygotowany akt prawny nie daje gwarancji odnośnie do jego społecznego odbioru? ${ }^{7}$ To, co jedni uważają za dobry pomysł na zmianę, innych skłania do obojętności bądź wrogości wobec organu ingerującego w zastany porządek. Kierując się tą przesłanką, powodzenie chińskich reform gospodarczych Poznański tłumaczy wpływem wzorów długiego trwania na postawy Chińczyków. W jego rozważaniach akcent pada na konfucjanizm scharakteryzowany za pomocą ośmiu dyrektyw etycznych. W doktrynie uchodzącej za osnowę chińskiego porządku społecznego ${ }^{8}$ ekonomista odnajduje klucz do rozwiązania nurtującego go problemu. Jeśli przyjąć, że etyka konfucjańska jest synonimem ładu spontanicznie reprodukowanego przez Chińczyków od V w. p.n.e., staje się jasne, dlaczego reformy Deng Xiaopinga się powiodły. Współgrały mianowicie z regułami tegoż ładu. Aby ocenić słuszność owego domniemania, warto zestawić program etyki konfucjańskiej z potrzebami i ograniczeniami społeczeństw współczesnych, w sposób szczególny z potrzebami - reformującego się - społeczeństwa chińskiego.

Poznański przedstawia konfucjański system wartości jako „sekwencję ośmiu założeń [...] tworzących rdzeń chińskiej [obyczajowości i - dop. P.R.] ekonomii”" Pierwsze z nich dotyczy ,jednostkowego poczucia celu”

7 R.D. Putnam, Demokracja w działaniu. Tradycje obywatelskie we współczesnych Włoszech, tłum. J. Szacki, Wyd. Znak, Kraków 1995.

${ }^{8}$ Wraz z taoizmem i buddyzmem.

${ }^{9}$ K. Poznański, op. cit., s. 62. 
wynikającego z przynależności człowieka do świata natury. Stwierdzenie to unaocznia, jak w omawianej doktrynie zobowiązania etyczne łączą się z założeniami metafizycznymi.

Konfucjaniści - wyjaśnia Poznański - nie mają co do tego wątpliwości, że [...] ludzie są integralną częścią świata natury. Aby zdefiniować podstawowy cel jednostki w życiu gospodarczym, należy najpierw zapytać, jaki może być cel od strony natury. Według konfucjanistów natura jest tym samym, co proces trwania, w którym każde organiczne stworzenie jest ożywiane swoistym kodem życia. Ten kod składa się z dwóch niezbędnych elementów zwanych yin i yang ${ }^{10}$.

W zaproponowanej formule rozważania dotyczące słusznego postępowania zostają poprzedzone namysłem nad ogólnym porządkiem rzeczy. Jednostka rozeznaje się we własnych powinnościach wtedy, gdy uświadamia sobie, jakie miejsce zajmuje w owym porządku. Dodatkową okolicznością utwierdzającą ją w przekonaniu o jej pomyślnym położeniu są reguły tegoż porządku. Świat jawi się jej jako miejsce przyjazne. Przyjazne, lecz nie bezproblemowe. Może w nim realizować cele cząstkowe tylko wtedy, gdy czyni to w harmonii z jej społecznymi partnerami oraz z przyrodą. Odwieczna harmonia wymienionych porządków to bowiem przepis na szczęście.

Drugie założenie jest rozwinięciem pierwszego. Optymizm, z jakim jednostka porusza się po świecie natury, bierze się stąd, że świat ów obfituje w dobra. Zamiast, typowej dla człowieka Zachodu, troski o szybko wyczerpujące się zasoby (decydujące o jakości jego życia oraz możliwości przetrwania) wyznawca Konfucjusza wierzy, iż natura wolna jest od takich ograniczeń. Poznański tłumaczy to następująco:

Stanowisko konfucjańskie głosi, że skoro ludzie w sposób naturalny mają potrzebę osiągania ciągłości, to natura musiała oczywiście stworzyć ludziom warunki materialne, w których może się to stale urzeczywistniać. Odpowiednio, ekonomia konfucjańska wychodzi z założenia, że w wymiarze uniwersalnym w czasie i przestrzeni - natura zapewnia ludziom wystarczające zasoby, włączając w to obfitość ziemi i wody oraz energii, tak by wytwarzać żywność itd. ${ }^{11}$

Dopowiedzmy, dobra, o których mowa, nie są czymś, po co wystarczy sięgnąć. Wyobrażenie natury jako pełnej spiżarni pomija istotne aspekty omawianej zależności. Aby natura w pełni zaspokajała potrzeby człowieka, musi on postępować zgodnie z jej prawami - dbać o nią, pielęgnować cnoty

\footnotetext{
10 Ibidem, s. 87.

11 Ibidem, s. 90.
} 
wewnętrzne oraz szanować innych ludzi. Tej prawidłowości (uzupełniającej tezę o nieograniczoności zasobów ekonomicznych) Poznański nadaje postać trzeciego założenia. Jak pisze:

Dla konfucjanistów przekonanie, że zasoby są niewyczerpalne, nie oznacza, że świat jest jakąś ziemią obiecaną albo rajem, gdzie wszystko jest podawane na talerzu ku zadowoleniu ludzi. Prawda jest taka, że po to, by zaspokoić swoje potrzeby, ludzie muszą przekształcić zasoby w dobra. Innymi słowy, muszą pracować, i stąd praca - wytwórczość - stanowi jedyne źródło wartości lub bogactwa ${ }^{12}$.

Kolejne założenia odnoszą się do (odwiecznych) praw natury, o których mowa w założeniu trzecim. Zgodnie z tą zapowiedzią założenie czwarte dotyczy motywów dowolnej działalności gospodarczej. W doktrynie Konfucjusza wykraczają one poza pragnienie własnej pomyślności. Wykraczają tak dalece, że owa pomyślność - niemal automatycznie - powiązana zostaje z potrzebami społecznego otoczenia jednostki reprezentowanego przede wszystkim przez jej rodzinę (klan). Poznański przypomina:

W ekonomii konfucjańskiej zakłada się, że mobilizacją do pracy jest troska o innych. Konfucjusz jednoznacznie stwierdzał: „Żyjesz dla innych, nie dla siebie”. Podobna jest wymowa spostrzeżenia na temat etyki życia poczynionego przez Mencjusza, który stwierdza, że: „Używanie świata, aby troszczyć się o kogoś, stanowi ostateczny sens troski”. Miał on na myśli to, że jednostki są motywowane troską nie o siebie, ale o innych, przede wszystkim o swoją rodzinę ${ }^{13}$.

Założenie piąte zawiera odpowiedź na pytanie o powód, dla którego powinności wobec rodziny (klanu) mają przewagę nad naszymi zobowiązaniami społecznymi. Z pomocą przychodzi zdrowy rozsądek. Z perspektywy jednostki rodzina jest miejscem, w którym dorasta ona, nabywa wiedzę i umiejętności przydatne w dorosłym życiu, przede wszystkim natomiast wytwarza więzi oparte na zaufaniu. Ostatni aspekt przeważa nad pozostałymi ze względu na jego doniosłość w procesie organizacji spraw teraźniejszych i przyszłych. Jednostka i jej bliscy mogą liczyć na siebie. Dla nich rodzina jest sumiennym nauczycielem, spolegliwym opiekunem i skutecznym egzekutorem zobowiązań wzajemnych. Tak opisuje ją Poznański:

Zakładając kluczową wagę moralności w procesie osiągania bogactwa, aby rodzina mogła odgrywać najważniejszą rolę w społeczeństwie jako „ogniwo

\footnotetext{
12 Ibidem, s. 93.

13 Ibidem, s. 95.
} 
pracy”, musi ona w decydujący sposób wpływać na poziom siły moralnej. Tak właśnie wygląda stanowisko konfucjanistów na temat podstawowej roli rodziny w organizacji gospodarki, bez względu na to, czy jest ona chińska. Uważają oni, że rodzina jest tą najważniejszą instytucją, ponieważ to z niej wywodzą się kodeksy moralne ${ }^{14}$.

Prawe postępowanie nie jest wynikiem rezygnacji z korzyści własnej uzasadnionej obawą kary czy obowiązkiem dotrzymania umowy zawartej przez jednostkę z członkami rodziny (bądź klanu). Rozróżnienie to dla konfucjanistów ma znikome zastosowanie. Zakładają oni raczej, że jedno powiązane jest z drugim. Właśnie wtedy, gdy jednostka bierze odpowiedzialność za innych, zwłaszcza za tych, z którymi przyszło jej żyć, maksymalizuje swoją pomyślność. Tego dotyczy szóste założenie. Ponoszenie odpowiedzialności przez jednostkę za jej - bliższe i dalsze - otoczenie to nic innego niż praktykowana przez nią gotowość dzielenia się własnym bogactwem. Kiedy nierówności będące skutkiem jej sukcesów (dokonań gospodarczych) przyczyniają się do obniżenia jakości życia wspólnotowego, powinna ona przeciwdziałać im za pomocą posiadanych środków. Celem tego działania poza indywidualną potrzebą okazywania współczucia - jest ochrona więzi społecznej (będącej jednym z parametrów jakości życia gospodarczego). Konfucjaniści uważają, że:

\begin{abstract}
dla osiągnięcia sukcesu gospodarczego niezbędna jest rygorystycznie przestrzegana, obejmująca całe społeczeństwo, zasada równości. Zastanawiając się nad miarą takiej egalitarnej dystrybucji, konfucjaniści uważają, że aby ocenić, jaki rodzaj dystrybucji najlepiej służy wzrostowi gospodarczemu, należy rozpocząć od zwrócenia uwagi na polityczne konsekwencje nierówności, włączając w to ubóstwo jako najbardziej skrajną ich postać. Założenie tego rodzaju sprawia, że konfucjanizm może się jawić jako ekonomia polityczna w sensie ekonomii klasycznej, którą w istocie jest ${ }^{15}$.
\end{abstract}

Założenie siódme rozwiewa niejasności towarzyszące wcześniejszemu przeciwstawieniu powinności rodzinnych i obowiązków społecznych jednostki. Klamrą łączącą oba zestawy wartości jest mianowicie państwo. Konfucjaniści wierzą, że aksjologiczna rozbieżność, o której mowa, nie musi skutkować dysfunkcjami społecznymi bądź gospodarczymi. Kluczem do sprawy jest polityka państwa umieszczającego jednostkę - od razu w środowisku rodzinnym (klanowym) przy równoczesnym przeniesieniu

\footnotetext{
14 Ibidem, s. 98.

15 Ibidem, s. 101.
} 
uprawnień do kierowania własnym losem na tę komórkę. Konsekwencją tego przesunięcia jest skorygowany obraz społeczeństwa składającego się z autonomicznie rozwijających się (mikro)wspólnot rodzinnych. Rolą władz politycznych jest ograniczenie ingerencji w ów spontanicznie reprodukujący się porządek do regulacji służących przeciwdziałaniu konfliktom pomiędzy rodzinami (aktywnymi społecznie i gospodarczo). Poznański nie ma wątpliwości, co do tego, że:

problemem, z którym musi zmierzyć się jakakolwiek szkoła ekonomii, jest stosunek państwa jako instytucji w odniesieniu do dwóch innych podmiotów, a mianowicie - odpowiednio - do jednostek oraz do rodziny. Podczas gdy w ekonomii liberalnej państwo minimalne jest preferowane, aby jednostki miały zapewnioną wolność realizowania swego losu, w ekonomii konfucjańskiej, jak się tego można domyślić, uzasadnieniem państwa minimalnego jest zapewnienie autonomii rodzinom. Państwa, co do których oczekuje się, że będą służyć rodzinom, najlepiej realizują tę funkcję poprzez ograniczanie swej interwencji tylko do tego, czego rodziny same nie są w stanie zrobić bardziej efektywnie. Wiedząc najlepiej, czego im trzeba, mówiąc inaczej - posiadając „,wiedzę wewnętrzną”, rodziny powinny być w stanie zatroszczyć się o większość swoich spraw z większym powodzeniem, niż zrobiłoby to państwo ${ }^{16}$.

Wreszcie ósme założenie odsłania fragment aksjonormatywnego kontekstu etyki konfucjańskiej odnoszący się do dominujących cech natury ludzkiej. Do tez o zasobności i harmonii świata dołącza przekonanie o „naturalnej dobroci” człowieka osiągającego szczęście nie tyle kosztem innych, ile poprzez współdziałanie z nimi. Poczucie niespełnienia towarzyszące osobom skupionym na korzyści własnej jest ostrzeżeniem i zachętą, by podążały one ku temu, co służy wszystkim. Przyjęte założenie antropologiczne znajduje przełożenie na sposób pojmowania ludzkiej sprawczości. Człowiek, w ujęciu konfucjańskim, nie dysponuje gotowym przepisem na życie. Przeciwnie, stawiając czoła problemom powszednim, musi zdać się na własną zmyślność. Nie jest w tym postępowaniu osamotniony, gdyż:

natura zapewnia [mu - dop. P.R.] nie tylko odpowiednie zasoby, ale także moralny kompas potrzebny do ich właściwego użytkowania. Mencjusz stwierdza to wyraźnie: „Nie ma człowieka, który by nie skłaniał się ku dobru”. Predyspozycja ta, jako wrodzona, co można określić mianem „naturalnej dobroci”, może zostać utracona za sprawą dwóch zagrożeń. Jednym z nich jest niezdolność do pielęgnowania cnotliwego zachowania - które jest

${ }^{16}$ Ibidem, s. 104. 
zadaniem nigdy się niekończącym. Inne - o wiele ważniejsze - zagrożenie to podporządkowanie się jednostek błędnym ideom. [...] Rozeznawanie „praw moralnych”, jako wyłącznego kodeksu, jest dla konfucjanistów kwestią o znaczeniu empirycznym, dotyczącą tego, czy czyjeś działania służą innym, czy raczej ich krzywdzą. Nie ma tu miejsca na spekulacje, gdyż tylko zbadanie praktyki społecznej może wyznaczyć, czy konkretna zasada - lub przepis - jest moralnie akceptowalny. Innymi słowy, w podejmowaniu takich moralnych kwestii nie ma miejsca na teorie poprzez tworzenie kategorii i budowanie modeli ${ }^{17}$.

Tylko doświadczenie społeczne uzupełnione o szacunek dla tradycji i reprezentujących ją mędrców w omawianej doktrynie uznane być mogą za podstawę prawidłowego wyboru środków służących zarazem budowaniu silnej gospodarki oraz maksymalizowaniu własnej pomyślności. To złożenie celów, zdaniem Poznańskiego, dowodzi, że w przypadku Chin mamy do czynienia z przekazem, który legł u podstaw nowej ekonomii. Dzięki etycznemu obramowaniu - właśnie dzięki niemu - skutecznie rywalizuje ona z jej zachodnią odpowiedniczką. Podczas gdy ekonomia klasyczna zapomniała, czemu ma służyć na dłuższą metę ochrona rynku i jego uczestników, ekonomia konfucjańska pamięta o człowieku zdefiniowanym jako istota społeczna.

\section{Depozyt tradycji - pomoc czy przeszkoda?}

Optymistyczne przesłanki Poznańskiego wiodą tymczasem do pytania o konsekwencje posługiwania się nimi. Zwłaszcza wtedy gdy - w zastosowaniu politycznym - nie tworzą one harmonijnej całości, wiele zdaje się przemawiać przeciwko nim. Aby rzetelnie odnieść się do kulturowej diagnozy badacza, należy zatem przywołać towarzyszące jej wątpliwości. Pierwsza z nich dotyczy roli rodziny w życiu społecznym. Trudno przecenić jej znaczenie. Rodzina uczy, wychowuje i integruje. Nie wynika z tego jednak, że właściwie wpływa na kształt stosunków społecznych. Jako pierwszy głos w sprawie zabiera Charles H. Cooley. Normom wpajanym jednostce w środowisku sąsiedzko-rodzinnym (neighbourhood) przeciwstawia on jej zobowiązania prawne i zawodowe ${ }^{18}$. Jako pracobiorca czy biznesowy partner zmuszona jest ona do uznania przewagi reguł organizacyjnych nad przywiązaniem do bliskich. Konflikt ów ma charakter obiektywny. Dbałość

${ }^{17}$ Ibidem, ss. 107-108.

${ }^{18}$ C.H. Cooley, The Social Organization, Prentice Hall, Englewood Cliffs, N.J. 1962. 
o miejsce pracy, jako norma poprawnościowa, z pozoru tylko redukuje się do etycznego pryncypium nakazującego troskę o innych ludzi. W społeczeństwie industrialnym rzeczona troska przejawia się tym, że przedmiotem paralelnej ochrony etycznej są przedsiębiorstwa dające zatrudnienie oraz rynek regulujący stosunki pomiędzy nimi. Czegóż zatem spodziewać się po ludziach (mimowolnie) kwestionujących ważność wymienionych pryncypiów?

Poruszoną kwestię rozstrzyga Francis Fukuyama. Za podstawowy mankament chińskiej rodziny uważa to, że drenuje ona społeczne otoczenie z kapitału więzi opartych na zaufaniu (nazywanego kapitałem społecznym). Im trwalsze są związki łączące jej członków, tym większa jest przepaść oddzielająca ich od reszty społeczeństwa ${ }^{19}$. Czyż może być inaczej? Zapewne tak. Cooley i inni symboliczni interakcjoniści zabiegali o to, by kapitał społeczny wytwarzany był w środowisku rodzinnym oraz poza nim, a zarazem dostrzegali, jak niewiele trzeba, by przedsięwzięcie to spaliło na panewce. Badacze analizujący owo zagrożenie - Pierre Bourdieu czy Alejandro Portes - wiążą je z negatywną postacią kapitału społecznego ${ }^{20}$. Pojęcie to odnosi się do praktyki współdziałania i wzajemnego dyscyplinowania się przez członków grupy pomnażającej korzyść własną kosztem reszty społeczeństwa. Tak funkcjonują przestępcy, przedsiębiorcy działający w zmowie czy członkowie zdeprawowanej korporacji zawodowej ${ }^{21}$. Najłatwiej jednak rodzinie (bądź klanowi) osiągnąć ten poziom zażyłości ${ }^{22}$. Kiedy więc jej członkowie utwierdzą się w przekonaniu, że „koszula bliższa ciału”, nie ma co liczyć na to, że włączą się oni w proces budowania społeczeństwa obywatelskiego (w nastawieniu innym niż manipulacyjne).

Druga wątpliwość dotyczy zgodności - kreślonego przez Poznańskiego - obrazu gospodarki chińskiej z danymi na jej temat gromadzonymi przez historyków i politologów. Zasadnicze znaczenie w badaniach dotyczących domniemanych narodzin nowej ekonomii (wzniesionej na konfucjańskim fundamencie) ma to, czy sukces Państwa Środka jest

${ }^{19}$ F. Fukuyama, Zaufanie. Kapitał społeczny a droga do dobrobytu, tłum. A. i L. Śliwa, Wydawnictwo Naukowe PWN, Warszawa 1997, ss. 85-101.

${ }^{20}$ A. Portes, Social Capital: Its Origins and Applications in Modern Sociology, „Annual Review of Sociology” 24/1998; P. Bourdieu, L.D. Wacquant, Zaproszenie do socjologii refleksyjnej, tłum. A. Sawisz, Oficyna Naukowa, Warszawa 2001.

21 Por. E. Hankiss, Pułapki społeczne, tłum. T. Kulisiewicz, Wiedza Powszechna, Warszawa 1986, ss. 109-110; A. Sen, Rozwój i wolność, tłum. J. Łoziński, Zysk i S-ka Wydawnictwo, Poznań 2002, s. 141.

22 Por. M. Puzzo, Ojciec chrzestny, tłum. B. Zieliński, Czytelnik, Warszawa 1991. 
konsekwencją zmian zachodzących pod wpływem świata zachodniego, czy przeciwnie - rezygnacji z tego, co ów świat ma do zaproponowania. Nie miejsce tu na omawianie długiej i zawiłej historii Chin. Nawet gdyby ograniczyć się do tego, co składa się na ich dzieje najnowsze, zakres spraw wymagających uwzględnienia skazywałby na niepowodzenie ów zamiar. Poprzestańmy zatem na przypomnieniu wydarzeń bezpośrednio powiązanych z przedmiotem rozważań podjętych w tym artykule ${ }^{23}$.

Polityka izolacjonistyczna prowadzona przez Państwo Środka do połowy XIX w. skutkuje ekspansją kolonialną (i terytorialną) państw zachodnich oraz Japonii. Trudno się temu dziwić. Spętane feudalnymi zaszłościami biurokratycznymi Chiny są w stanie politycznej zapaści. Po śmierci cesarza Guangxu w 1908 r. wybucha rewolucja Xianhai. Jej rezultatem jest proklamowanie Republiki Chińskiej (1911) oraz detronizacja mandżurskiej dynastii Qing (1912). Działania te nie przynoszą przełomu. Przeciwnie, są początkiem - trwającego do roku 1949 - etapu walk pomiędzy zwolennikami ustroju (liberalno-)monarchistycznego a komunistami. W 1932 r. Japończycy opanowują Mandżurię. Pięć lat później atakują Chiny, zajmując ich znaczną część, z Pekinem włącznie. Skłania to komunistów i nacjonalistów do zawieszenia bratobójczych walk w celu utworzenia wspólnego frontu antyjapońskiego. Po kapitulacji Japonii w 1945 r. i nieudanej próbie utworzenia rządu koalicyjnego obie frakcje ponownie zwracają się przeciwko sobie. W 1946 r. wybucha kolejna wojna domowa, w której zwycięstwo odnoszą komuniści. W wyniku tego w 1949 r. utworzona zostaje Chińska Republika Ludowa. Na czele nowego państwa staje Mao Zedong.

Mao w okresie walk komunistów o władzę daje się poznać jako utalentowany strateg. Niestety, talentów tych nie umie wykorzystać w warunkach pokoju. Do jego największych porażek należy program przebudowy gospodarki chińskiej realizowany w latach 1958-1962 (tzw. wielki skok) oraz rewolucja kulturalna przypadająca na ostatnią dekadę życia Mao. W pierwszym przypadku pustoszy on gospodarkę, w drugim natomiast doprowadza Chiny na skraj anarchii. Przełom przynosi jego śmierć w 1976 r. oraz aresztowanie bandy czworga (polityków z bezpośredniego otoczenia Mao usiłujących po jego śmierci przejąć kontrolę nad armią). Na fali krytyki maoizmu do głosu dochodzi Deng Xiaoping. Pod koniec 1978 r. inicjuje

${ }^{23}$ Podstawą - naprędce dokonanej - rekonstrukcji są następujące prace: W. Rodziński, Historia Chin, Zakład Narodowy im. Ossolińskich, Wrocław-Warszawa-Kraków 1992; J. Fairbank, Historia Chin, Wyd. Bellona, Warszawa 2003; W.S. Morton, C.M. Lewis, Chiny: historia i kultura, Wyd. Uniwersytetu Jagiellońskiego, Kraków 2007. 
on proces przywracania autorytetu państwa oraz przebudowy gospodarki chińskiej. Pomysł okazuje się przysłowiowym strzałem w dziesiątkę. Reformy skutkują gwałtownym wzrostem produkcji rolnej i przemysłowej.

Xiaoping działa metodycznie ${ }^{24}$. W pierwszym okresie reform (1979-1984) jego celem jest osiągnięcie samowystarczalności żywnościowej. Ziemię należącą do komun ludowych oddaje on w dzierżawę rodzinom rolniczym. W wyniku tego sprzedaż produktów rolnych na wolnym rynku zwiększa się z 5,6\% do 18,1\%25. W latach 1984-1990 - w drugim etapie - akcent położony zostaje na inwestycje w produkcję przemysłową oraz rozwój instytucji finansowych. Powstają specjalne strefy ekonomiczne. W tym okresie następuje niespotykany wzrost liczby przedsiębiorstw zagranicznych działających w Chinach. Od zaledwie kilkudziesięciu firm tolerowanych w czasach Mao liczba ta dochodzi do 200 000. Ostatnim, trzecim etapem chińskich reform (po Tiananmen) jest otwieranie się państwa na potrzeby społeczeństwa przeobrażającego się równie dynamicznie jak gospodarka ${ }^{26}$. Znika część ograniczeń dotyczących uczestnictwa w publicznej debacie, wyznawania tradycyjnie chińskich religii, kształtowania własnego stylu życia, a przede wszystkim angażowania się w przedsięwzięcia biznesowe.

Jakie znaczenie w analizie przyczyn chińskiego sukcesu gospodarczego mają przytoczone fakty? Odpowiedź na to pytanie zawiera się w zestawieniu trzech aspektów tego zagadnienia: zapóźnień cywilizacyjnych Chin (do początku XX w.), kontrowersji towarzyszących poszukiwaniu dróg wyjścia z impasu, a wreszcie treści reform '78 roku. Nie sposób pominąć tu symboli zaczerpniętych z chińskiej tradycji. Niestety, nie dostarczają one poszukiwanego rozwiązania. To, co integruje społeczeństwo chińskie, kształtuje jego przekonania normatywne, jeszcze sto lat temu jawiło się jego elitom jako staroć wymagający pilnego zastąpienia cudzymi wzorami kultury gospodarczej i politycznej. Można zaryzykować twierdzenie, że zapożyczenia od innych skłoniły Chińczyków do odnalezienia rozwiązań

24 J.Kofan,W.Roszkowski,ReformysystemowewChinach,http:// www.studiapolityczne. pl/files/sp3/kofman_roszkowski_reformy_systemowe_w_chinach.pdf, dostęp: 13.10.2018; D. Xiaoping, Chiny na drodze reform w XXI wieku, Wyd. Adam Marszałek, Toruń 2012.

${ }^{25}$ E. Cieślik, Rolnictwo w Chinach: rozwój, wyzwania i problemy, s. 21, http://sj.wne. sggw.pl/pdf/PRS_2013_T13(28)_n2_s19.pdf; s. 21, dostęp: 8.02.2019; A. Watson, The Reform of Agricultural Marketing in China since 1978, „China Quarterly” 113/1988.

${ }^{26}$ M. Żmuda, Przyczyny wejścia chińskiej republiki ludowej na ścieżkę przyspieszonego wzrostu gospodarczego, w: W. Michalczyk (red.), Wybrane problemy gospodarki światowej pierwszej dekady nowego wieku, Uniwersytet Ekonomiczny we Wrocławiu, Wrocław 2009, ss. 93-101. 
ukrytych w ich kulturowym depozycie. W żadnym razie natomiast nie wolno traktować owych rozwiązań jako przesłanki kompleksowo wyjaśniającej to, co zaszło w Chinach. Poczyniona uwaga odsyła do elementów pominiętych w tym wnioskowaniu. W państwie, którego żywnościowym priorytetem była „miska ryżu dziennie”, postanowiono uczynić atut z tego, co było główną przyczyną jego wcześniejszych niepowodzeń. Silna władza administracyjna posłużyła się mechanizmem rynkowym. Nie tracąc kontroli nad nim, mogła udzielić gwarancji bezpieczeństwa rzeszy inwestorów przybywających do Chin. Owszem, w tym procesie znaczącą rolę odegrali chińscy chłopi. Jako dzierżawcy ziemi rozwiązali oni problem niedoborów żywności. Nie oni jednak ugruntowali pozycję Chin jako światowej potęgi gospodarczej. Uczyniły to firmy, dla których Państwo Środka stało się miejscem atrakcyjniejszym ekonomicznie niż rodzimy Zachód.

\section{Czy chińscy komuniści są konfucjanistami? Podsumowanie}

W ostatnich stu latach Chiny przebyły bardzo długą drogę. Długą do tego stopnia, że łatwo zapomnieć o problemach, z którymi społeczeństwo chińskie zmagało się przed wstąpieniem na nią. Zmagało się mianowicie z wzorami długiego trwania utrudniającymi mu wyrwanie się z kilkusetletniego mara$\mathrm{zmu}^{27}$. Chińczycy usilnie poszukiwali nowych wzorów kultury politycznej. Nie tylko one jednak spędzały im sen z powiek. Jeśli wierzyć Fukuyamie, nie mniej kłopotliwe okazały się (bądź okazują) reguły uczestnictwa w życiu zbiorowym nakazujące troskę o własną rodzinę kosztem zobowiązań społecznych. Łącząc jedno z drugim, chińska droga do dobrobytu wiodła nie tylko przez sferę publiczną, lecz - w równym stopniu - przez serca i umysły Chińczyków. Tymczasem w okresie gospodarczej prosperity górę w owych sercach bierze tęsknota za przeszłością. Miejsce doktryn zapożyczonych ze świata zachodniego oraz wiedzy o skali zachodnich inwestycji zajmuje nostalgia ${ }^{28}$. Polityczne nawiązania Deng Xiaopinga do nauk Konfucjusza w okamgnieniu zamienione zostają w przekaz o znaczeniu podstawowym ${ }^{29}$. Nie dziwi

\footnotetext{
27 F. Braudel, op. cit., s. 55.

28 Por. J. Sowa, Fantomowe ciało króla. Peryferyjne zmagania z nowoczesna forma, Wyd. Universitas, Kraków 2011, ss. 183-205, 323-349, 468-476.

29 J. Marszałek-Kawa, Koncepcja nauki, szkoły i wychowania w ujęciu Deng Xiaopinga. Fragmenty przemówień z lat 1938-1992, Wyd. Adam Marszałek, Toruń 2013, ss. $110-158$.
} 
postawa Chińczyków pragnących zapomnieć o własnej historii. Czymś innym natomiast jest niepamięć zewnętrznych obserwatorów zmian zachodzących w tym kraju.

Zwolennicy tezy o porządkujących walorach etyki konfucjańskiej powielają błąd Maxa Webera popełniony przez niego (jakże symptomatycznie) na przełomie XIX i XX w. O ile pomyłka Webera dotyczyła światopoglądowych zatorów spowalniających rozwój gospodarczy Chin, o tyle jego współcześni naśladowcy z zatorów tych czynią zasób kulturowy decydujący o powodzeniu wdrażanych przez nie reform. Pomyłce tej przygląda się (między innymi) Peter L. Berger. Świadomy - diagnostycznych i prognostycznych - skutków jej przeoczenia postanawia wyjaśnić, jak do niej dochodzi. W podsumowaniu swoich dociekań stwierdza, co następuje:

Okazało się, że historia gospodarcza Azji Wschodniej obaliła Weberowskie koncepcje dotyczące empirycznych konsekwencji tego, co nazywał „magicznym ogrodem azjatyckiej religijności”. Zrozumiałe więc, że pewni badacze usiłowali, można by tak powiedzieć, postawić Webera na głowie tzn. znaleźć takie elementy we wschodnioazjatyckiej kulturze, zwłaszcza zaś w tradycji religijnej, które można by interpretować jako pozytywne predyspozycje do nowoczesnej przedsiębiorczości gospodarczej. Przedsięwzięcie takie pociąga za sobą poważne problemy metodologiczne. Zawsze istnieje niebezpieczeństwo błędu post hoc, ergo propter hoc - gdy coś się już wydarzy, poszukuje się przyczyn w zdarzeniach wcześniejszych, które nie muszą być przyczynami (ten błąd niektórzy krytycy Webera zarzucali jego pracy o protestantyzmie jako czynniku sprawczym kapitalizmu); religia i etyka mogą raczej legalizować, a nie motywować zachowania gospodarcze; postawa wysoce racjonalna i postawa wysoce „magiczna” mogą współcharakteryzować tę samą jednostkę (zwłaszcza w „pluralistycznej” Azji), tak że ryzykowne jest przyjmowanie założenia, że istnieje jakiś koherentny system wartości determinujący zachowania gospodarcze ${ }^{30}$.

Z krytyki Bergera nie wynika, że teza Kazimierza Poznańskiego o związkach zachodzących pomiędzy tradycją konfucjańską a modelem gospodarczym Deng Xiaopinga (nazwanym „socjalistyczną gospodarką rynkową”31) jest fałszywa. Z krytyki tej wynika raczej, że związki, o których mowa,

30 P.L. Berger, Rewolucja kapitalistyczna, tłum. Z. Simbierowicz, Oficyna Naukowa, Warszawa 1995 ss. 269-270; por. K. Samuelsson, Protestantyzm a kapitalizm. Krytyka teorii M. Webera, tłum. J. Grosfeld, „Znak” 7/1984.

31 Zob. np. M.O. Suliman (red.), China's Transition to a Socialist Market Economy, Greenwood Publishing Group, 1998. 
nie mają koniecznego charakteru. Powodzenie reform Xiaopinga równie dobrze uzasadnia konfucjańska wrażliwość Chińczyków co niskie koszty produkcji w miejscu, w którym za zatrudnionymi stoi „rezerwowa armia bezrobotnych”32, przed nimi natomiast państwo egzekwujące przestrzeganie (nader restrykcyjnego) prawa. Oba czynniki należy zatem wziąć pod uwagę w badaniach dotyczących przyczyn chińskiego cudu gospodarczego. Podążając tym tropem, warto pochylić się nad dodatkowym aspektem badanego zagadnienia. Są nim podobieństwa pomiędzy (tradycyjnymi) przekonaniami Chińczyków na temat tego, jak być powinno, a stanowiskiem Chińskiej Partii Komunistycznej sięgającej po instrumenty rynkowe w procesie kierowania społeczeństwem (nominalnie) socjalistycznym.

To wyraźnie heterodoksyjne podejście chińskich komunistów do doktryny Marksa rzuca światło na ich (ukryte) intencje. Nie rezygnując z programu określającego ich polityczną tożsamość, za warunek prawidłowego posługiwania się nim uznali oni umiejętność dopasowania go do oczekiwań, nawyków i możliwości rozwojowych zwykłych ludzi. Posługując się słownikiem nauk społecznych, preferowaną przez siebie wizję porządku stanowionego postanowili oni skorelować z - zakorzenionymi w chińskiej kulturze i tradycji - regułami ładu spontanicznego. Domniemanie to współgra z ósmym założeniem Poznańskiego nakazującym wyznawcom Konfucjusza otwieranie się na praktykę społeczną nawet wtedy, gdy odbywa się to kosztem teorii systematyzującej wiedzę o niej. Ponadto polityka Chińskiej Partii Komunistycznej po 1978 r. koresponduje z założeniami etyki konfucjańskiej odnoszącymi się do równościowych pryncypiów oraz nakazu ponoszenia przez jednostkę odpowiedzialności za jej społeczne otoczenie. Podobieństwa tymczasem nie powinny przesłaniać różnic. Nadużyciem byłoby twierdzenie, że obie perspektywy aksjologiczne pokrywają $\mathrm{się}^{33}$. Nie jest to zresztą konieczne. To, co upodabnia je do siebie, daje podstawę po temu, by przyjąć, że łączy je związek funkcjonalny.

Ma rację Poznański, głosząc, że przebudowa gospodarki chińskiej nie powiodłaby się bez społecznego przyzwolenia na nią obejmującego uświadomione korzyści z uczestnictwa w tym procesie. Ma rację również w tym, że owe korzyści wykraczają poza to, co składa się na interes partykularny

${ }^{32}$ K. Marks, F. Engels, Manifest komunistyczny, Warszawa 1966, s. 71.

33 Przeczy temu ostrożne wycofywanie się państwa chińskiego z polityki kontroli populacji. Aplikacyjnie nieprzydatne wydają się również konfucjańskie założenia o nieograniczoności zasobów ekonomicznych, doskonałości świata natury czy wrodzonej dobroci człowieka. 
jednostek i grup lokalnych. Osobnego uwzględnienia wymagają dobroczynne skutki reintegracji społeczeństwa chińskiego wokół wspólnie podzielanych wartości. Myli się jednak Poznański, zawężając listę owych wartości do tych wywiedzionych z tradycji konfucjańskiej, a następnie stawiając znak równości pomiędzy nimi a projektem (nowej) ekonomii chińskiej. Konieczne w czynnościach rekonstrukcyjnych tego rodzaju jest uwzględnienie dwóch dodatkowych czynników. Są nimi: inicjatywa komunistów implementujących zasady „socjalistycznej gospodarki rynkowej” oraz przyczyny, dla których zachodni establishment zdecydował się przenieść produkcję do Chin. Dopiero w tej konfiguracji (czynników sprawczych) badania Kazimierza Poznańskiego dotyczące zmian w Państwie Środka mogą dać odpowiedź na pytanie o determinanty rozwojowe, którym zawdzięcza ono swoją uprzywilejowaną pozycję.

\section{Literatura}

Bendix R., Max Weber. Portret uczonego, tłum. K. Jakubowicz, Państwowe Wydawnictwo Naukowe, Warszawa 1975.

Berger P.L., Rewolucja kapitalistyczna, tłum. Z. Simbierowicz, Oficyna Naukowa, Warszawa 1995.

Bourdieu P., Wacquant L.D., Zaproszenie do socjologii refleksyjnej, tłum. A. Sawisz, Oficyna Naukowa, Warszawa 2001.

Braudel F., Gramatyka cywilizacji, Oficyna Naukowa, Warszawa 2006.

Cieślik E., Rolnictwo w Chinach: rozwój, wyzwania i problemy, http://sj.wne.sggw.pl/pdf/ PRS_2013_T13(28)_n2_s19.pdf, dostęp: 8.02.2019.

Cooley C.H., The Social Organization, Prentice Hall, Englewood Cliffs, N.J. 1962.

Fairbank J., Historia Chin, Wyd. Bellona, Warszawa 2003.

Fukuyama F., Zaufanie. Kapitał społeczny a droga do dobrobytu, tłum. A. i L. Śliwa, Wydawnictwo Naukowe PWN, Warszawa 1997.

Goodman D.S.G., Deng Xiaoping and the Chinese Revolution: A Political Biography, Routledge, London 1994.

Hankiss E., Pułapki społeczne, tłum. T. Kulisiewicz, Wiedza Powszechna, Warszawa 1986.

Kofan J., Roszkowski W., Reformy systemowe w Chinach, http:// www.studiapolityczne.pl/files/sp3/kofman_roszkowski_reformy_systemowe_w_chinach.pdf, dostęp: 13.10.2018.

Kozyr-Kowalski S., Gesellschaft ohne Wirtschaft: formy recepcji Maxa Webera w socjologii amerykańskiej, w: R. Bendix, Max Weber. Portret uczonego, tłum. K. Jakubowicz, Państwowe Wydawnictwo Naukowe, Warszawa 1975.

Marks K., Engels F., Manifest komunistyczny, Warszawa 1966.

Marszałek-Kawa J., Koncepcja nauki, szkoły i wychowania w ujęciu Deng Xiaopinga. Fragmenty przemówień z lat 1938-1992, Wyd. Adam Marszałek, Toruń 2013. 
Morton W.S., Lewis C.M., Chiny: historia i kultura, Wyd. Uniwersytetu Jagiellońskiego, Kraków 2007.

Polit J., Chiny, Wyd. Trio, Warszawa 2004.

Portes A., Social Capital: Its Origins and Applications in Modern Sociology, „Annual Review of Sociology” 24/1988.

Poznański K., Ekonomia jako etyka. Podejście konfucjańskie, w: E. Mączyńska, J. Sójka (red.), W stronę nowego paradygmatu, PTE, Warszawa 2017.

Putnam R.D., Demokracja w działaniu. Tradycje obywatelskie we współczesnych Włoszech, tłum. J. Szacki, Wyd. Znak, Kraków 1995.

Puzzo M., Ojciec chrzestny, tłum. B. Zieliński, Czytelnik, Warszawa 1991.

Rodziński W., Historia Chin, Zakład Narodowy im. Ossolińskich, Wrocław-WarszawaKraków 1992.

Samuelsson K., Protestantyzm a kapitalizm. Krytyka teorii M. Webera, tłum. J. Grosfeld, „Znak” 7/1984.

Sen A., Rozwój i wolność, tłum. J. Łoziński, Zysk i S-ka Wydawnictwo, Poznań 2002.

Sowa J., Fantomowe ciało króla. Peryferyjne zmagania z nowoczesną formq, Wyd. Universitas, Kraków 2011.

Wallerstein I., The Modern World-System. The Second Era of Great Expansion of the Capitalist World-Economy, 1730-1840's, New York 1974.

Watson A., The Reform of Agricultural Marketing in China since 1978, „China Quarterly” 113/1988.

Xiaoping D., Chiny na drodze reform w XXI wieku, Wyd. Adam Marszałek, Toruń 2012.

Żmuda M., Przyczyny wejścia chińskiej republiki ludowej na ścieżkę przyspieszonego wzrostu gospodarczego, w: W. Michalczyk (red.), Wybrane problemy gospodarki światowej pierwszej dekady nowego wieku, Uniwersytet Ekonomiczny we Wrocławiu, Wrocław 2009. 